\title{
RANCANG BANGUN PURWARUPA SISTEM GENERAL CHECK-UP KESEHATAN MANUSIA BERBASIS MIKROKONTROLLER ARDUINO UNO R3
}

\author{
Harun Sujadi ${ }^{1)}$, Tri Ferga Prasetyo ${ }^{2)}$ Mochamad Farziki Lazuardi ${ }^{3)}$ \\ Program Studi Teknik Informatika, Fakultas Teknik, Universitas Majalengka \\ Email:harunsujadi@gmail.com, triferga.prasetyo@gmail.com, farzikilazuardi07@gmail.com
}

\begin{abstract}
The development of technology and science is very advanced, especially communication technology, we can find out about various kinds of technological innovations created to help human life. One of them is microcontroller technology that provides benefits in life including in general examination in the world of health. General examination is one of the checks in the world of health in hospitals or health centers. The number of health complaints in Indonesia itself, especially the countryside quite a lot. However, it has not been balanced with regular checks, therefore health complaints in Indonesia, especially the countryside are very large, many ways that can be done by the Indonesian population, especially the countryside, to check their own health so that health complaints in Indonesia can be reduced by checking to the nearest health center or hospital. From what was explained above, I made a general check-up system to make it easier and faster to check in the puskesmas. In this general check-up system uses microcontroller components, ultrasonic sensors, DS18B20 type temperature sensors and load cell sensors which are integrated with hardware components namely bluetooth HC-05, after being integrated and connected to the general check-up application will appear in the form of a value on the smartphone android.
\end{abstract}

Keywords - general check-up system, microcontroller, android smartphone.

\section{Pendahuluan}

Jumlah persentasi penduduk yang mengalami keluhan kesehatan menurut data statistik atau Badan Pusat Statistik mulai tahun 2014 di perkotaan mencapai $28,57 \%$ dan di tahun 2015 keluhan kesehatan di indonesia meningkat sebesar $1,76 \%$ dari total $30,33 \%$, dan pada tahun $2016 \mathrm{di}$ perkotaan mengalami penurunan lagi sebesar $1,54 \%$ dari total $28,79 \%$, dan pada tahun 2014 keluhan kesehatan di indonesia mencapai $29,87 \%$, dan di tahun 2015 keluhan kesehatan di indonesia meningkat sebesar $0,49 \%$, dari total $30,36 \%$, dan pada tahun 2016 keluhan kesehatan di indonesia menurun lagi sebesar 2,1\%, dari total $28,26 \%$, penduduk di indonesia, di banding dari tahun 2014 sampai 2016 keluhan kesehatan di indonesia di perkotaan dan pedesaan sangatlah menurun drastis pada pedesaan sampai menurun $2,1 \%$ jelas lebih besar dibanding perkotaan jika cenderung mengikuti pola nasional dari yang sudah di jelaskan di atas menurut Badan Pusat Statistik masih kurangnya tingkat kesadaran penduduk untuk memeriksakan dirinya ke puskesmas terdekat yang ada di daerahnya masing-masing, maka dari itu penduduk pedesaan jauh lebih turun drastis dibandingkan penduduk perkotaan. Berdasarkan keadaan yang demikian maka perlunya sebuah solusi untuk meminimalisir pemborosan waktu dan suatu data dapat di ambil secara bersamaan agar mempermudah dokter atau ahli kesehatan medis mendapatkan suatu data di puskesmas tersebut, maka perlu di rancang sebuah penelitian yang berjudul "Rancang Bangun Purwarupa Sistem General Check-Up Kesehatan Manusia Berbasis Mikrokontroller Arduino Uno R3". Dimana Sistem General Check-Up tersebut mampu memberikan suatu data atau Output secara bersamaan serta saling terintegrasi ke dalam smartphone pemilik (user) melalui koneksi bluetooth, supaya General Check-Up tersebut bisa dimonitoring dengan jarak yang cukup jauh..

Berikut merupakan teori-teori yang berhubungan dengan penelitian ini.

a. Penelitian yang dilakukan Adi Prasetyo dkk, pada tahun 2015 dengan judul "Monitoring Suhu Tubuh Pasien Demam Berdarah Menggunakan Bluetooth Yang Diintegrasikan Ke Personal Komputer". Penelitian ini menemukan bahwa alat pendeteksian perubahan suhu tubuh pasien wabah demam berdarah dari fase awal, fase kritis dan fase penyembuhan menggunakan mikrokontroller, dan untuk Sarana interfacenya menggunakan beberapa rangkaian digital yang terdiri dari Sensor Suhu Digital dan Bluetooth HC-05. Untuk memproses sinyal yang dihasilkan oleh 
rangkaian interface, maka dibuat software menggunakan Pemrograman C++. Software ini juga berfungsi untuk menampilkan suhu tubuh pasien di LCD dan sebagai perintah untuk mengirim data melalui bluetooth ke personal computer di ruang perawat dengan waktu real time dan simultan, Persamaan dengan penelitian yang saya akan buat adalah memonitoring atau mendeteksi suhu tubuh manusia yang outputnya berupa nilai dari sensor tersebut dan yang akan di tampilkan melalui smartphone android untuk penelitian saya. (Prasetyo, Monitoring Suhu Tubuh Pasien Demam Berdarah Menggunakan Bluetooth Yang Diintegrasikan Ke Personal Komputer, 2015).

b. Penelitian yang dilakukan Edwar Frendi Yandra dan Boni Pahlanop, pada tahun 2016 dengan judul "Rancang Bangun Timbangan Digital Berbasis Sensor Beban $5 \mathrm{Kg}$ Menggunakan Mikrokontroler Atmega328". Penelitian ini menemukan bahwa alat yang di rancang dan yang akan di buat adalah alat timbang elektronik dan mikrokontroller sebagai pengendali dan alat timbang elektronik ini hanya mencapai beban tidak lebih dari $5 \mathrm{~kg}$ dan alat ini juga mampu mengukur massa jenis benda menggunakan sensor ultrasonik mksudnya di sini untuk menghitung kenaikan benda, persamaan dengan penelitian yang saya akan buat adalah menampilkan hasil output berupa nilai yang di dapatkan oleh sensor beban tersebut tetapi saya menggunakannya dengan sensor beban yang 10kg. (Yandra, 2016)

c. Penelitian yang dilakukan Eko Sulistyo pada tahun 2016 dengan judul "Alat Pendeteksi Denyut Nadi Berbasis Arduino Yang Diinterfacekean Ke Komputer". Penelitian ini menemukan bahwa sebuah alat pengukuran denyut nadi secara real time yang dapat di hubungkan dengan komputer dan perhitungan denyut nadi dengan pulse sensor ini secara digital dan di proses oleh arduino mega 2560 dan di tampilkan melalui LCD, persamaan dengan penelitian yang saya akan buat adalah sama-sama menggunakan pulse sensor tetapi pulse sensor yang saya gunakan untuk mendeteksi berapa bytes per minutes (BPM) detak jantung pada manusia dan untuk outputnya itu sendiri sangat berbeda yang saya outputnya berupa nilai yang di tampilkan melalui smartphone android dan untuk penelitian sebelumnya outputnya berupa nilai yang di tampilkan melalui LCD digital. (Sulistyo, Alat Pendeteksi Denyut Nadi Berbasis Arduino Yang Diinterfacekan Ke Komputer, 2016)

d. Penelitian yang dilakukan Muhammad Afdali dkk, pada tahun 2017 dengan judul "Perancangan Alat Ukur Digital untuk Tinggi dan Berat Badan dengan Output Suara Berbasis Arduino UNO". Penelitian ini menemukan bahwa alat ukur tinggi badan dan berat badan serta memberikan suatu informasi ideal atau tidaknya berat badan yang terukur dan alat ini menggunakan arduino Uno sebagai otaknya sensor ultrasonik untuk mengukur tinggi badan dan sensor strain gauge untuk mengukur berat badan dan untuk outptnya berupa suara dari speaker, persamaan dengan penelitian yang saya akan buat adalah sama-sama menggunakan sensor ultrasonik untuk tinggi badan dan untuk berat badannya itu sendiri saya berbeda dengan penelitian sebelumnya saya menggunakan sensor berat badan load cell dan outputnya berupa nilai dari suatu sensor yang di tampilkan melalui smartphone android. (Afdali, Perancangan Alat Ukur Digital Untuk Tinggi Dan Berat Badan Dengan Output Suara Berbasis Arduino Uno, 2017)

e. Penelitian yang dilakukan I Ketut Resika Arthana dkk, pada tahun 2018 dengan judul "Sistem Monitoring Detak Jantung dan Lokasi Pasien". Penelitian ini menemukan bahwa menggunakan protokol zigbe penelitian ini bermanfaat untuk mengetahui lokasi kondisi pasien dari jarak jauh persamaan dengan penelitian yang saya akan buat adalah mendeteksi detak jantung pada tubuh manusia yang outputnya berupa nilai Bytes Per Minutes (BPM). (Arthana, 2018)

f. Penelitian yang dilakukan I Ketut Resika Arthana dkk, pada tahun 2018 dengan judul "Sistem Monitoring Detak Jantung dan Lokasi Pasien". Penelitian ini menemukan bahwa menggunakan protokol zigbe penelitian ini bermanfaat untuk mengetahui lokasi kondisi pasien dari jarak jauh persamaan dengan penelitian yang saya akan buat adalah mendeteksi detak jantung pada tubuh manusia yang outputnya berupa nilai Bytes Per Minutes (BPM). (Arthana, 2018) 
g. Penelitian yang dilakukan oleh Sujadi, H., \& Bastian, A. (2018). Design prototype detection tools of Porous Tree using microcontroller Arduino Uno R3 and piezoelectric sensor. In Journal of Physics: Conference Series tentang Arduino Uno R3

\section{Metode Penelitian}

Untuk memudahkan pemahaman tahapantahapan yang penulis lakukan dalam penelitian ini maka dibuatlah kerangka penelitian. Kerangka penelitian tugas akhir dapat dilihat pada gambar 1

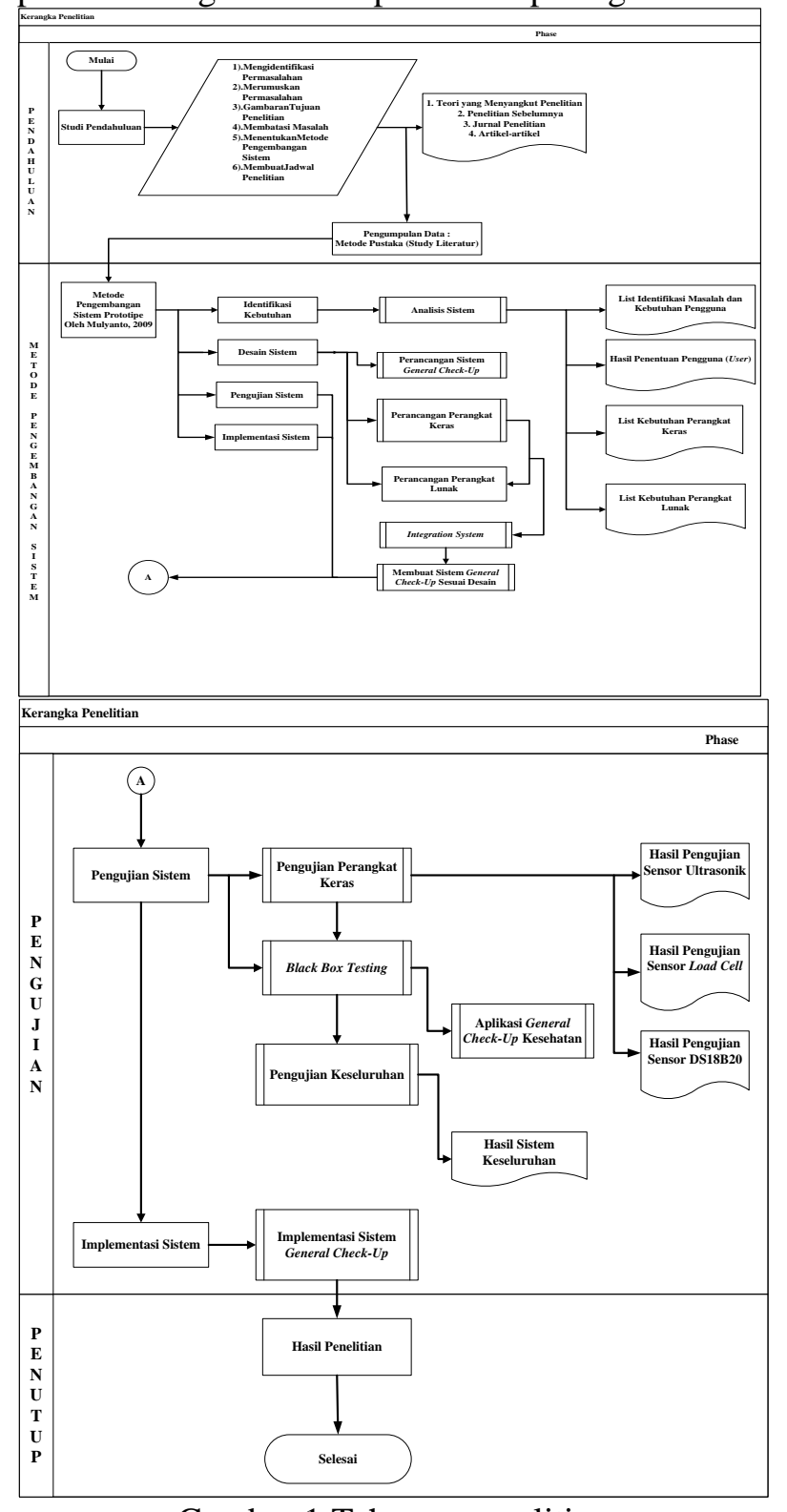

Gambar 1 Tahapan penelitian

Dalam kerangka penelitian tugas akhir ini, terdiri dari empat tahap yaitu sebagai berikut :

1. Pendahuluan
Phase pertama yaitu studi pendahuluan. Dalam tahap ini dimulai dari mengidentifikasi permasalahan pada sistem general check-up yang ada di puskesmas, merumuskan permasalahan yang terjadi, membatasi masalah, menentukan tujuan yang ingin dicapai dalam penelitian, menentukan metode pengembangan sistem yang akan digunakan, mewujudkan manfaat yang dicapai dalam penelitian ini serta membuat jadwal penelitian. Selain itu dalam tahap ini menjelaskan mengenai metode pengumpulan data dengan menggunakan metode pustaka (Metode Pengumpulan Data).

2. Metode Pengembangan Sistem

Phase yang kedua yaitu tahap metodologi penelitian. Dalam tahap ini menjelaskan mengenai metodologi yang digunakan dalam mengembangkan sistem, yaitu metode prototype. Dimana dalam metode prototype terdapat 4 tahap yaitu analisis kebutuhan, desain sistem, pengujian sistem, implementasi sitem. Tahap analisis kebutuhan merupakan tahap dari analisis sistem. Dalam tahap analisis sistem ini akan menganalisis masalah, analisis pengguna (user), analisis kebutuhan perangkat keras (hardware) dan analisis kebutuhan perangkat lunak (software). Selanjutnya masuk ke tahap desain sistem yang didalamnya dilakukan desain general checkup, rancangan hardware dan software. Dilanjutkan dengan tahap integration system yaitu untuk menghubungkan hasil design hardware dan software menggunakan media bantu berupa bluetooth membuat sistem keamanan sesuai desain dan kebutuhan pada tahap sebelumnya.

3. Pengujian

Dalam tahap ini masuk ke dalam pengujian sistem dengan menggunakan dua Teknik. Sebagai berikut :

a. Pada pegujian black box testing pengujian yang dilakukan adalah pengujian aplikasi yang terintegrasi dengan komponen hardware.

b. Sedangkan untuk pengujian yang kedua menitik beratkan pengujian sesuai fungsi dari tiap komponen hardware. Setelah tahapan pengujian sesuai dengan fungsinya, tahapan selanjutnya adalah tahapan implementasi sistem yang 
menghasilkan pengujian dari beberapa pengguna (user).

\section{Penutup}

Phase terakhir dalam kerangka penelitian tugas akhir ini adalah menghasilkan Rancang Bangun Purwarupa Sistem General Check-Up Kesehatan Manusia Berbasis Mikrokontroller Arduino Uno R3.

\section{HASIL DAN PEMBAHASAN}

Pada penelitian ini dilakukan beberapa tahapan yaitu menganalisis kebutuhan sistem, perancangan usulan sistem.

\section{a. Analisis Kebutuhan Sistem}

Tahapan ini bertujuan untuk mengidentifikasi masalah dan kebutuhan spesifik sistem. Kebutuhan spesifik sistem adalah spesifikasi mengenai hal-hal yang akan dilakukan sistem ketika diimplementasikan antara lain : masukan yang diperlukan sistem (input), keluaran yang dihasilkan (output), operasioperasi yang dilakukan (proses), sumber data yang ditangani dan Pengendalian (kontrol).

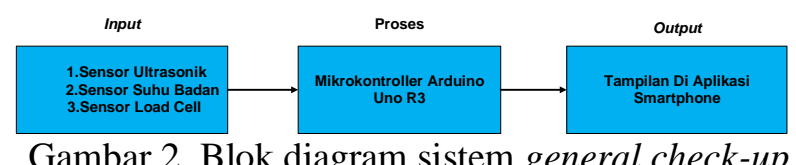

Gambar 2. Blok diagram sistem general check-up

b. Perancangan Usulan Sistem

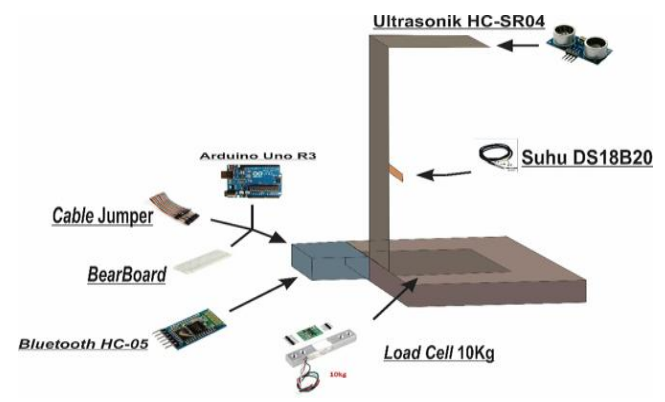

Gambar 3. Perancangan Sistem Usulan

Gambar 3 menunjukkan skema sistem usulan. Dalam rangkaian sistem ini berisi diagram keseluruhan sistem secara garis besar tapi tetap menjelaskan dan menggambarkan cara kerja dari sistem general check-up. Penjelasan gambar 3 adalah sebagai berikut:

1) Dibagian paling atas tihang pipa paralon terdapat sebuah sensor ultrasonik HC-SR04 yang digunakan untuk mengukur tinggi badan atau benda yang diintegrasikan dengan bluetooth yang outputnya tampil pada sebuah smartphone
2) Di bagian tengah tihang paralon terdapat 1 buah sensor sebelah kiri yaitu sensor suhu badan manusia DS18B20 yang diintegrasikan dengan bluetooth yang outputnya tampil pada sebuah smartphone.

3) Di bagian paling bawah dan sejajar dengan sensor ultrasonik yaitu sensor load cell $10 \mathrm{Kg}$ untuk mengukur berat badan atau benda yang di atasnya yang diintegrasikan dengan bluetooth yang outputnya tampil pada sebuah smartphone.

Tabel 1 Pin-pin I/O Arduino Uno R3

\begin{tabular}{cll}
\hline \hline No & $\begin{array}{l}\text { Nama } \\
\text { Perangkat } \\
\text { Keras }\end{array}$ & $\begin{array}{l}\text { Pin pada Arduino } \\
\text { Uno R3 }\end{array}$ \\
\hline \hline 1 & $\begin{array}{l}\text { Sensor } \\
\text { ultrasonic }\end{array}$ & Digital 4,5 \\
2 & $\begin{array}{l}\text { Sensor LOAD } \\
\text { CELL }\end{array}$ & Digital 2 \\
3 & Sensor & Digital 1 \\
& DS18B20 & \\
\hline
\end{tabular}

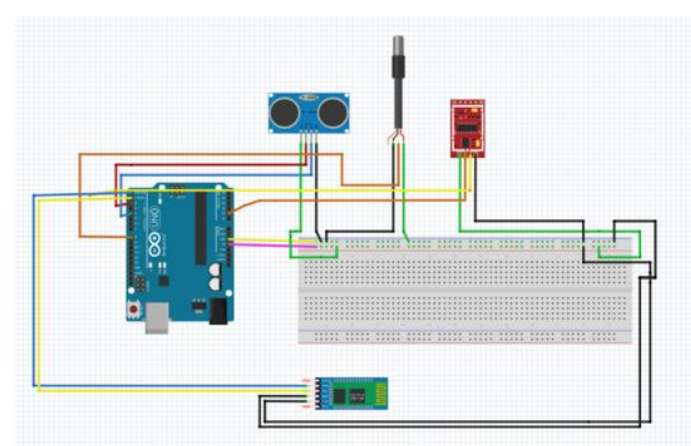

Gambar 4. Rangkaian sistem general check-up Pada bagian ini membahas mengenai hasil pengujian system yang sudah dilakukan

\section{a. Pengujian Sistem}

Pengujian ini dilakukan terhadap Rancang bangun purwarupa system general check-up kesehatan manusia berbasisi mikrokontroller arduino uno R3 terutama bagian perangkat keras atau sensor yang terlibat dalam sistem tersebut. Pengujian ini bertujuan untuk mengetahui kinerja dari sistem general check-up. Pada pengujian tersebut dilakukan 5 (lima) kali percobaan. Untuk menghitung presentase tingkat keberhasilan digunakan rumus:

Persentase $=\frac{\text { Percobaan Berhasil }}{\text { Banyak Percobaan }} \times 100 \%$

1. Sensor Berat Badan (Load Cell) 
Tujuan pengujian dan analisis/pembahasan yang dilakukan pada sensor load cell adalah untuk mendapatkan parameter tentang keakuratan sensor saat mendeteksi tekanan pada berat benda atau manusia.

Tabel 2 Pengujian Sensor Load Cell

\begin{tabular}{lll}
\hline \hline No & Perobaan Ke- & Keberhasilan \\
\hline \hline 1 & 1 & Tidak Sesuai \\
2 & 2 & Sesuai \\
3 & 3 & Tidak Sesuai \\
4 & 4 & Sesuai \\
5 & 5 & Sesuai \\
\hline
\end{tabular}

Berdasarkan pengujian respon sensor load cell yang sudah dilakukan. Dapat ditarik kesimpulan bahwa persentase tingkat keberhasilan dari pengujian sensor load cell adalah $80 \%$.

2. Sensor Ultrasonik

Tujuan pengujian dan analisis/pembahasan yang dilakukan pada sensor ultrasonik adalah untuk mendapatkan parameter tentang keakuratan sensor saat mendeteksi jarak manusia ketika berdiri di bawah sensor ultrasonik. Dalam pengujian ini dihitung juga dimana untuk Panjang jarak pada penempatan sensor dengan ujung dasar sensor load cell yang sudah ditetapkan yaitu $57 \mathrm{~cm}$.

\begin{tabular}{|c|c|c|}
\hline No & $\begin{array}{l}\text { Perobaan } \\
\text { Ke- }\end{array}$ & Keberhasilan \\
\hline 1 & 1 & Tidak Sesuai \\
\hline 2 & 2 & Sesuai \\
\hline 3 & 3 & Sesuai \\
\hline 4 & 4 & Sesuai \\
\hline 5 & 5 & Sesuai \\
\hline
\end{tabular}

Berdasarkan pengujian respon sensor ultrasonik yang sudah dilakukan. Dapat ditarik kesimpulan bahwa persentase tingkat keberhasilan dari pengujian sensor ultrasonik adalah $80 \%$.

\section{Sensor Suhu Badan DS18B20}

Tujuan pengujian dan analisis/pembahasan yang dilakukan pada sensor DS18B20 adalah untuk mendapatkan parameter tentang keakuratan sensor saat mendeteksi suhu badan manusia ketika sensor di masukan kedalam ketiak.

\begin{tabular}{cll}
\multicolumn{2}{c}{ Tabel 3 Pengujian } & Sensor DS18B20 \\
\hline \hline No & Perobaan & Keberhasilan \\
& Ke- & \\
\hline \hline 1 & 1 & Sesuai \\
2 & 2 & Sesuai \\
3 & 3 & Sesuai \\
\hline \hline
\end{tabular}

\begin{tabular}{lll}
\hline 4 & 4 & Sesuai \\
5 & 5 & Sesuai \\
\hline
\end{tabular}

\section{KESIMPULAN}

Berdasarkan hasil pengujian yang telah dirancang dan dibangun, maka kesimpulan penelitian dengan judul "Rancang Bangun Purwarupa Sistem General Check-Up Kesehatan Manusia Berbasis Mikrokontroller Arduino Uno R3" yaitu sebagai berikut :

1. General Check-Up sistem ini dengan Arduino menggunakan bahasa pemrograman $\mathrm{C}$, kemudian diintegrasikan dengan perangkat keras hardware berupa bluetooth untuk bisa dikontrol melalui smartphone android dengan melakukan perancangan hardware dan software menggunakan metode pengembangan sistem Prototipe. Sistem General check-Up ini juga meningkatkan kualitas dan efektifitas paramedis dalam bekerja.

2. Mikrokontroller Arduino Uno R3 diintegrasikan dengan menggunakan media transmisi melalui perangkat keras (Hardware) berupa bluetooth. Dan perancangan pada interface sistem general check-up ini menggunakan aplikasi offline yaitu MIT APP Inventor dan pada bahasa pemogramannya itu sendiri menggunakan java.

3. Sistem General Check-Up yang sudah di uji cobakan dari 3 sensor dan di integrasikan dengan perangkat keras hardware yaitu berupa bluetooth dan di tampilkan pada smartphone android berhasil tampil, tapi dari pengujian tersebut masih ada tingkat akurasi kesalahan pada setiap sensor yang digunakan.

\section{DAFTAR PUSTAKa}

Fajarianto, O. (2017). Sistem Penunjang Keputusan Seleksi Penerimaan Karyawan Dengan Metode Weighted Product. 1.

Frendi Yandra, E., Pahlanop Lapanporo, B., \& Ishak Jumarang, M. (2016). Rancang Bangun Timbangan Digital Berbasis Sensor Beban 5 Kg. 23-28.

Hidayat, M. (2014). Sistem Informasi Manajemen Berbasis Desktop Pada Dept Harga. Tanggerang. 
Izzatul Islam, H. (2016). Sistem Kendali Suhu Dan Pemantauan Kelembaban Udara Ruangan Berbasis Arduino Uno Dengan Menggunakan Sensor DHT22. 5.

Kadir, A. (2003). Pengenalan Sistem Informasi. Yogyakarta: Andi.

Kumala. B. A. (2018). Indikator Level Air Menggunakan Sensor HC-SR04 Dengan Lampu RGB Dan Aplikasi Android Melalui Bluetooth.

Sujadi, H., \& Bastian, A. (2018, May). Design prototype detection tools of Porous Tree using microcontroller Arduino Uno R3 and piezoelectric sensor. In Journal of Physics: Conference Series (Vol. 1013, No. 1, p. 012163). IOP Publishing. 